\title{
Praktyki epistemiczne głuchych
}

Praktyki "widzenia" osób głuchych nie są z konieczności naturalne czy logiczne, w tym sensie, że mają oni bardziej rozwinięty zmyst wzroku, ich praktyki "widzenia" sa nastęsstwem dtugiej historii wzajemnego oddziatywania ze światem w określony sposób - w sposób kulturowy (Padden, Humphries 2005: 2).

\section{Wstęp. O dziwności głuchych ${ }^{1}$}

\begin{abstract}
$\mathrm{A}_{8}$ naliza. To jest ich mocna strona na pewno. Byłam dzisiaj świadkiem godzinnego wykładu na temat wyższości jednego modelu telefonu skomunikowanego z budzikiem wibracyjnym zakładanym na rękę niczym zegarek nad innym modelem. Nawet nie sądziłam, że można na tyle aspektów jednego zagadnienia zwrócić uwagę. Cena, to oczywiste. Żywotność baterii. Długość
\end{abstract}

1 W kontekście szeroko omawianego w literaturze (por. Podgórska-Jachnik 2013, 17-163) rozróżnienia między sposobami zapisu tego słowa "głuchy" a "Głuchy" kontrowersyjna może się wydawać przyjęta w artykule pisownia "głuchy". Ta konwencja ortograficzna przyjęta została przeze mnie w pełni świadomie. Po pierwsze, nie do końca zgadzam się z przyjmowaną za anglojęzycznym dyskursem Deaf studies konwencją ortograficzną g/Głuchy jako nieposiadającą pełnego uzasadnienia w kontekście gramatyki i ortografii języka polskiego. Dodatkowo uważam, że w kontekście polskim trudność w akceptacji wyrazu "głuchy” związana jest z jego silnym negatywnym emocjonalnym nacechowaniem („głuchy" to słowo obraźliwe). W moim przekonaniu właśnie używanie funkcjonującego w polskim słowniku wyrazu "głuchy" i jednoczesna próba rekonfiguracji, poszerzenia, zmiany znaczenia tego słowa jest tym działaniem, które może najpełniej dopomóc w walce z dyskryminacją. 
czasu ładowania. Moc wibracji. Kolorystyka paska i wyświetlacza. Kształt baterii wewnątrz budzika. Ładowarka do baterii w budziku zintegrowana z obudową, tj. z paskiem. Możliwość zainstalowania dodatkowych aplikacji.

No i opowiada M. o tym telefonie i opowiada. A potem dzieli się ze mną informacją o tym, że podczas budowy domu ze względów podatkowych lepiej zbudować garaż w bryle domu, a nie potem jako oddzielny budynek. Bo on się dowiedział, jak budował dom. Jak go zapytałam o podstawę prawną, to mi nie potrafił powiedzieć. Ale wiedział, że tak jest z własnego doświadczenia. I powiedział mi to z troski o mnie. „Żebyś wiedziała, jak będziesz budować dom”2.

Przypomniałam sobie o tym fragmencie, kiedy na grupie facebookowej obejrzałam vloga, w którym głuchy mężczyzna snuje rozważania na temat wyboru deskorolek. Znowu ta sama szczegółowość co do kształtu, koloru, napędu, ułożenia nóg, ceny itd. Równocześnie nieraz byłam uczestnikiem rozmów z głuchymi, w których zdawali się oni nie rozumieć najprostszych rzeczy, zwłaszcza tych związanych z regułami życia społecznego. Dlaczego nie ma ulgowych biletów MPK dla głuchych? I moje ulubione pytanie, które pada na rozmowie kwalifikacyjnej: Kiedy mogę wziąć urlop?

Pytanie, jakie stawiam w tym artykule, dotyczy praktyk epistemicznych osób głuchych. Przez praktyki epistemiczne rozumiem zarówno treść wiedzy osób głuchych, jak i sposób dochodzenia do tej wiedzy, zdobywania jej. Przedmiotem moich rozważań stanie się w szczególności sposób, w jaki wiedza jest budowana poprzez sensorium. Chcę pokazać, że odniesienia do zmysłowości występują dwutorowo. Na poziomie dyskursu, którego tematem stają się możliwości osoby głuchej, czyli takiej, która posiada określone doświadczenie cielesne. Na poziomie znaku migowego, gdzie takie elementy, jak ruch i wizualność, kształtują określone somatosensoryczne praktyki epistemiczne głuchych. W swoich rozważaniach sięgam do przykładu vlogów zamieszczonych na stronie Głucha Polka Potrafi.

\section{Deaf Can}

Badaczka epistemologii głuchych Goedele DeClerk (2012: 29) wskazuje na trzystopniowy model emancypacji głuchych. Stopień pierwszy opisuje stan społeczności głuchych znajdujących się pod wpływem oralizmu, podporządkowanych i wycofanych z życia społecznego. Drugi stopień emancypacji oznacza

2 Cytat z notatki terenowej. Projekt badawczy, do którego efektów odwołuję się w tym artykule, był prowadzony przeze mnie na przestrzeni lat 2009-2013 w paradygmacie badań w działaniu. Przez ten okres regularnie spotykałam się w ramach podejmowanych działań z grupą ponad 500 dorosłych osób głuchych z terenu województwa łódzkiego i wielkopolskiego. Do świetlic w kołach terenowych prowadzonych przez Polski Związek Głuchych Oddział Łódzki (Łódź, Piotrków Trybunalski, Skierniewice, Wieluń, Kutno, Tomaszów Mazowiecki) jeździłam regularnie (raz w miesiącu do każdej ze świetlic) przez okres od września do 2011 do kwietnia 2013. W ramach realizowanych działań miałam także kontakt z uczniami szkół dla głuchych w Łodzi, Poznaniu, Kutnie, Rydzynie i Żarach. 
upolitycznienie kwestii tożsamości głuchych za sprawą legitymizacji języka migowego, która dokonała się dzięki badaniom językoznawczym. Wreszcie trzeci stopień emancypacji dotyczy stanu, w którym młode głuche osoby traktują bycie głuchym jako jeden $\mathrm{z}$ aspektów różnorodności $\mathrm{w}$ pluralistycznym społeczeństwie, z łatwością komunikują się transnarodowo, a także w niektórych przypadkach rozwijają swoją transnarodową głuchą tożsamość. Wydarzenia, które dały początek międzynarodowemu dyskursowi o możliwościach głuchych osób, przyporządkować można do drugiego stopnia wspomnianego modelu.

Jak zauważa Katherine Jankowski w odniesieniu do sytuacji społeczności głuchych w USA w przededniu pamiętnych wydarzeń na Uniwersytecie Gallaudeta:

Lata 60-te i 70-te XX wieku to czas, w którym ruch społeczny Głuchych przesuwał się w stronę ukonstytuowania społeczności Głuchych jako grupy językowej i kulturowej posiadającej własną tożsamość. Separatystyczna retoryka, która była świadectwem zmieniającej się świadomości w obrębie społecznego ruchu Głuchych w tamtym okresie utorowała drogę do wzmocnienia retoryki możliwości. Społeczny ruch Głuchych zaczął łączyć nową świadomość z żądaniami zwiększenia udziału osób głuchych w instytucjach społecznych i edukacyjnych, które związane były bezpośrednio ze środowiskiem osób głuchych (Jankowski 1997: 99) ${ }^{3}$.

Wydarzenia z marca 1988 roku, które miały miejsce na Uniwersytecie Gallaudeta w Waszyngtonie, były związane z żądaniem powołania osoby głuchej na stanowisko rektora tej uczelni. Żądania przybrały formę strajku głuchych studentów (Jankowski 1997: 99-136). Jednym z głównych tematów protestów było: can the can't syndrom, co w amerykańskim języku migowym stanowiło swoistą grę słów. Kilkakrotne powtórzenie znaku migowego $C A N^{\prime} T^{4}$ (ang. nie móc) używane było jako określenie „syndromu niemocy”, czyli sytuacji, w której osoby głuche doświadczają sytuacji i komunikatów odnoszących się do tego, czego nie mogą robić ze względu na własną głuchotę. Znak can the can't syndrom polegał na tym, że kolejne powtórzenia znaku migowego $C A N^{\prime} T$ wykonywane były w taki sposób, aby zmienić jego znaczenie na bardziej pozytywne. Postulat ten dotyczył $\mathrm{w}$ gruncie rzeczy potrzeby i determinacji odczuwanej przez uczestników protestu, którzy sprzeciwiali się podkreślaniu niemocy osób głuchych oraz dążyli do szerszego uświadomienia ich rzeczywistych możliwości. Zakończony sukcesem protest na Uniwersytecie Gallaudeta w Waszyngtonie stał się dla osób głuchych w USA i na całym świecie nie tylko symbolem emancypacji czy uwolnienia się od audystycznej opresji ze strony słyszących, ale także momentem przełamania dotychczasowego sposobu mówienia o głuchych. Nowy dyskurs miał odtąd wskazywać na pozytywne aspekty bycia głuchym i tym samym wspomagać budowanie pozytywnej tożsamości przedstawicieli tej grupy.

Tłumaczenia cytatów z publikacji anglojęzycznych pochodzą od autorki tekstu.

4 To oraz następne wyrazy cytowane bezpośrednio z języka migowego zostały zapisane zgodnie z zasadami przyjętymi w The Leipzig Glossing Rules. 
Strategie wykorzystywane podczas protestu studentów na Uniwersytecie Gallaudeta odnosiły się nie tyle do głuchoty jako pewnego wyobrażenia wspólnoty osób, co raczej do głuchoty będącej symptomem określonych praktyk cielesnych. Jedno z wydarzeń z marca 1988 roku w sposób szczególny obrazuje ten właśnie aspekt. Pierwszego dnia strajku na kampusie, 7 marca 1988 roku, Jane Spilman, przewodnicząca Rady Fundatorów Uniwersytetu Gallaudeta, została wyprowadzona na plac przed jednym z budynków, gdzie zebrali się protestujący. Jej celem było ogłoszenie stanowiska Rady (po jej ponownym zebraniu) w sprawie żądań protestujących studentów. Spilman miała poinformować, że Rada nadal nie wyraża zgody na żądania studentów. Ale zanim to powiedziała, jeden z pracowników uczelni, głuchy Harvey Goodstein, zamigał do zebranych, że Rada nie zamierza w ogóle brać pod uwagę żądań studentów. Harvey Goodstein zamigał też, żeby wszyscy się rozeszli. Ponieważ Spilman nie znała języka migowego, nie wiedziała, dlaczego studenci zaczęli odchodzić i nie rozumiała sytuacji, w jakiej się znalazła. Opuszczający plac studenci bardzo hałasowali, uruchomił się także alarm przeciw pożarowy. Spilman powiedziała, że Rada nie zamierza wysłuchać żądań studentów, którzy krzyczą tak głośno, że hałas uniemożliwia dialog. Na te słowa studenci odpowiedzieli: „Jaki hałas?” i „Gdybyś migała, to byśmy cię usłyszeli". Jak zauważa Jankowski (1997: 121):

To symboliczne użycie dźwięku pokazuje coś przeciwnego do popularnego wyobrażenia ludzi głuchych jako "cichych”, studenci nie byli cicho. Co więcej, byli oni bardzo świadomi dźwięku i wykorzystali go jako swój atut. Ogromny hałas nie jest tak kłopotliwy dla ludzi głuchych jak dla słyszących. Rozumiejąc to, protestujący celowo generowali tak wielki hałas, jaki tylko byli w stanie stworzyć, po to, żeby zagrać władzom uczelni na nosie i robili to właśnie w najbardziej irytujący sposób.

Odpowiedź skierowana do pani Spilman: „Gdybyś migała, to byśmy cię usłyszeli” dotyczyła nie tylko żądania dostępności komunikacyjnej. Była to lekcja głuchej cielesności. To, co protestujący chcieli wtedy przekazać, bardzo mocno związane było z ich cielesnym byciem w świecie. Kondycja cielesna głuchej osoby i komunikowanie się w języku migowym tworzą nową jakość, która może stanowić alternatywę dla powszechnie panującego pięciozmysłowego status quo z nadrzędną pozycją zmysłu słuchu. Pokazanie, że „nam hałas nie przeszkadza” to zwrócenie uwagi na różnice między głuchymi i słyszącymi m.in. w zakresie praktyk epistemicznych.

Informacje związane ze zmysłem słuchu można zignorować. To, co jest dla słyszących niepoddającym się relatywizacji intensywnym doświadczeniem cielesnym na granicy fizycznego bólu, dla głuchych mogło stać się przedmiotem pewnej gry symboli oraz zostać włączone w porządek wyobrażeniowy. W tym tkwi sens dyskursywnej praktyki mówienia o tym, co głuchy może (am. jęz. mig.: DEAF CAN). To, w jaki sposób wykorzystywane jest ciało, może zostać dostrzeżone tylko w kontakcie z innymi ludźmi i przedmiotami w ramach jakiegoś określonego środowiska lub habitusu (Howes 2003: 31). Teresa Blankmeyer Burke (2014) 
zwraca uwagę na konieczność badań empirycznych tego, w jaki sposób osoby głuche działają i funkcjonują w świecie. Koncentrowanie się jedynie na językowych aspektach bycia głuchym może stawiać w obliczu czegoś, co Blankmeyer Burke nazywa „wyzwaniem CODA ${ }^{5}$. Kognitywne korzyści wynikające z używania i akwizycji języka migowego mogą bowiem dotyczyć $w$ równym stopniu osoby głuchej, jak i słyszącej, np. dzieci głuchych rodziców. Autorka wskazuje zatem na inne aspekty głuchoty, które można rozpatrywać w kategoriach korzyści (ang. Deaf gain). Chodzi mianowicie o możliwość wyboru i sprawowania kontroli nad własnym "fenomenologicznym doświadczeniem sensorycznym", co może dotyczyć między innymi wyczuwania wibracji podłoża generowanych przez fale dźwiękowe ${ }^{6}$ albo widzenia muzyki ${ }^{7}$. Opanowanie dźwięku to przykład kontroli sensorycznej. Zdobywanie i przekazywanie wiedzy o tym, jak posługiwać się dźwiękiem, stanowi praktykę epistemiczną osób głuchych, które żyją w świecie dźwięków (Bahan 2014: 250-251).

W badaniu epistemicznych praktyk osób głuchych skierowałam uwagę na dyskursywną praktykę mówienia o tym, co „Głuchy może”. W ostatnich kilku latach w Polsce powstały liczne inicjatywy, które wpisują się w ten dyskurs, w szczególności vlogi na facebookowej stronie Głucha Polka Potrafi, projekt Inspide, a także wystąpienia publiczne głuchej Miss Deaf International 2016 Iwony Cichosz. W dalszej części tekstu przybliżę działania w ramach projektu "Głucha Polka Potrafi".

\section{"Głucha Polka Potrafi"}

"Głucha Polka Potrafi" to pierwszy w Polsce projekt motywacyjny dla osób głuchych, w całości prowadzony w polskim języku migowym. Na stronie internetowej projektu zamieszczane są m.in. wywiady wideo z ciekawymi osobami głuchymi, ogłoszenia o warsztatach, a także blog. W materiale z 15 października 2014 roku Iwona Krawczuk opowiada o historii powstania projektu. Inspiracją do jego rozpoczęcia były książki z serii Polka potrafi autorstwa Magdy Bębenek, które wywołały w Iwonie wiele nowych, choć nie do końca sprecyzowanych pomysłów. Kiedy dowiedziała się, że Bębenek zaczęła poszukiwać praktykantek, które miałyby pomagać w promowaniu książek, Iwona odezwała się do autorki. W ten sposób kobiety nawiązały współpracę, która zaowocowała pomysłem na "szerzenie motywacji i inspiracji wśród osób niesłyszących". W ramach projektu Krawczuk pokazuje osoby głuche, które osiągnęły w swoim życiu sukces:

CODA stanowi skrót od a child of deaf adult (pol. dziecko dorosłej osoby głuchej).

6 Przykładem może być Mandy Harvey, bohaterka amerykańskiego „Mam talent” - film z jej występu pojawił się na Facebooku Głucha Polka Potrafi 8 czerwca 2017 roku.

7 Obrazuje to głucha artystka Christine Sun Kim - link na blogu Głucha Polka Potrafi z 20 września 2016 roku. 
podróżują, prowadzą biznes, mają ciekawą pracę. Bohaterkami i bohaterami bloga Iwony są prawie wyłącznie osoby głuche komunikujące się w języku migowym

Analizie poddanych zostało 11 wywiadów ${ }^{9}$ oraz wypowiedzi Iwony Krawczuk, autorki projektu. Po dokładnym zapoznaniu się z wywiadami w pierwszej kolejności skupiłam się wyłącznie na wyodrębnieniu tych fragmentów wypowiedzi, w których znalazło się bezpośrednie odniesienie do głuchoty, tj. pojawił się znak migowy "GŁUCHY”. Następnie analiza wybranych fragmentów doprowadziła do wyodrębnienia kilku motywów odnoszących się do następujących pytań badawczych: czy i w jaki sposób w wypowiedziach osób głuchych pojawiają się odniesienia do głuchoty rozumianej jako doświadczenie cielesne? W jaki sposób wiedza budowana jest poprzez sensorium? Poniżej zaprezentowane zostały wnioski płynące z przeprowadzonej analizy.

\section{Głuchota nazwana}

Bezpośrednie odniesienia do głuchoty pojawiają się w każdym z wywiadów. Albo prowadząca, albo rozmówca - najczęściej zaś oboje - uznają za stosowne doprecyzowanie, że wypowiedź odnosi się do osób głuchych, np.: „inny głuchy mi powiedział, żeby spróbować", ,szkolenia wyłącznie dla głuchych tłumaczy", "była tam sekcja dla osób niepełnosprawnych, ale dla głuchych nic nie było", „,czy oglądają stronę słyszący czy głusi?", "głuchy fotograf z Anglii”, „pokazać przez obrazy jak wygląda życie głuchych", „dużo osób głuchych przyszło z dziećmi”, "chodzi o to, że głuchy próbuje przekazać coś słyszącemu za pomocą swojego alfabetu”, „komiks dla głuchych", „rady dla głuchych artystów i grafików”.

Czym w kontekście praktyki epistemicznej jest to bezpośrednie wskazywanie na głuchotę? Po pierwsze, jest to gest ustanowienia owej praktyki i jednocześnie gest jej uprawomocnienia. Wskazać bezpośrednio na głuchotę to jak powiedzieć: to, co mówię, odnosi się do doświadczenia osoby głuchej i dlatego jest ważniejsze, lepsze, prawdziwsze niż doświadczenie osoby słyszącej. Nazywanie głuchoty to tworzenie rysy na dyskursie wytwarzanym przez słyszących, to przerywanie tego dyskursu, to wychodzenie poza niego.

Symptomatyczny pod tym względem jest film opublikowany na blogu "Głucha Polka Potrafi" 1 listopada 2016 roku, opatrzony postem "Coś o naszej kulturze z całego świata”. Ukazuje on głuchych żyjących w różnych częściach

$8 \quad$ Tylko jeden wywiad jest przeprowadzony z osobą słabosłyszącą, Kate Zamana, która nie posługuje się językiem migowym, oraz jeden z osobą słyszącą, właścicielką „Different - Restauracji w ciemności". Oba wywiady przeprowadzone zostały z udziałem tłumacza języka migowego. 9 Analizowane były następujące wywiady: Magdalena Bielak-Kościńska, psycholog, właścicielka firmy zajmującej się prowadzeniem kursów polskiego języka migowego; Iwona Cichosz, aktorka, zdobywczyni tytułu Miss Deaf International; Renata Świderska, przewodnicząca Komitetu ds. Głuchych Tłumaczy w Europejskim Forum Tłumaczy w EFSLI; Monika Kozub, graficzka, stażystka w biurze Europejskiej Unii Głuchych w Brukseli; Joanna Jasińska, masażystka; Katarzyna Stępień, projektantka sutaszu, właścicielka marki KAVRILA; Justyna Kieruzalska, graficzka, malarka; Radka Novakowa, kierująca działem wiadomości dla głuchych w czeskiej telewizji publicznej, Leszek Daszkowski, emigrant mieszkający na Islandii. 
świata, migających różnymi językami migowymi, wykonujących rozmaite zawody, prowadzących własne firmy, pokonujących bariery, które napotykają na swojej drodze. W ostatniej części filmu dowiadujemy się, że mimo wielu różnic kulturowych głuchych z całego świata łączy wyraźna więź, która wynika ze wspólnego cielesnego doświadczenia i „dawania sobie rady”. Bohaterowie filmu wypowiadają w różnych językach migowych zdanie: "Jestem głuchy”. W ten sposób zaświadczają o własnym doświadczeniu sensorycznym. Choć posługują się różnymi językami migowymi i żyją razem ze słyszącymi w różnych kulturach na całej Ziemi, to jednak wszyscy są właśnie głusi.

\section{Poszerzanie pola}

Kolejnym składnikiem praktyki epistemicznej głuchych jest poszerzanie pola. Rozumiem przez to strategię polegającą na wskazywaniu, w jakich obszarach życia społecznego, które z definicji jest zdominowane przez osoby słyszące, osoby głuche funkcjonują z sukcesem. Dzięki wywiadom dowiadujemy się o głuchych aktorach, głuchych projektantach biżuterii, głuchych właścicielach firm, głuchych emigrantach, głuchych masażystach, głuchych fotografach, głuchych stażystach, głuchych grafikach, głuchych historykach itd.

Aby w pełni zrozumieć istotę tej strategii, należy wskazać dyskurs, wobec którego jest ona wymierzona. Założenie milcząco przyjmowane w tym dyskursie ma charakter aksjologiczny: słyszenie jest lepsze niż niesłyszenie, głuchota. Słyszenie jest uznawane za normę, zaś głuchota jest skrajnym odstępstwem. Głuchota jest uznawana za bezpośrednią przyczynę licznych ograniczeń. Być głuchym, to nie móc słyszeć. Nie móc słyszeć, to nie móc się komunikować i nie móc funkcjonować w społeczeństwie. Opisane założenie przejawia się na wiele, często zniuansowanych sposobów, ale na ogół prowadzi do tego samego zdziwienia:

- Jakie były reakcje ludzi, gdy w programie okazało się, że jesteś głucha?

- Byli zaskoczeni. Dziwili się, że jako osoba głucha pracuję w teatrze. Zrobione ze mną wywiad w programie „Uwaga”. Dla nich to było nowością, a dla mnie to jest normalne. Nie widzę przeszkód w byciu aktorką ${ }^{10}$.

Poszerzanie pola wynika z kilku przesłanek. Po pierwsze, jest odpowiedzią na znane głuchym ryzyko uwewnętrzniania przez nich poglądów dominujących w społeczeństwie złożonym w przeważającej części z osób słyszących. Po drugie, ma wymiar walki ze stereotypem albo - innymi słowy - przeciwstawiania się oczywistemu kłamstwu. Jak głuchota może być synonimem niemocy, skoro istnieją dowody, że jest dokładnie odwrotnie? Po trzecie wreszcie, poszerzanie pola jest praktyką o charakterze informacyjnym. Ponieważ dyskurs migowy ma zasięg ograniczony, trzeba nieustannie przekazywać w nim informacje ważne, istotne, kluczowe. Trzeba mówić, jak naprawdę wygląda życie różnych głuchych osób. Trzeba informować o tym, co naprawdę mogą robić osoby głuche.

10 Wywiad z Iwoną Cichosz, min. 11:40 i dalej, http://www.gluchapolkapotrafi.pl/wywiady. 


\section{Opowieści o sposobach działania}

W każdym z wywiadów kolejnym elementem charakterystycznym jest opis sposobu działania: „,siedziałam i analizowałam dokładnie tą technikę”, „namawiał mnie kolega, ale nie za bardzo go słuchałam, więc najpierw przekonał mojego męża, żeby przekonał mnie i po dwóch tygodniach namów męża zgodziłam się", "porozmawiałam z innym głuchym o tym", "słuchając wykładu głuchej dziennikarki zrozumiałam, że powinnam wysłać swoją ofertę, a nie wycofywać się". Pokazanie sposobu działania to nic innego, jak podanie przykładu z życia osoby głuchej. Dopóki sytuacja nie zostanie opowiedziana w języku migowym, nie istnieje $\mathrm{w}$ rezerwuarze doświadczenia kulturowego głuchych. Opowieściom o sposobach działania towarzyszą opowieści o emocjach. Te ostatnie pojawiają się najczęściej w związku z koniecznością dostosowywania się lub przekraczania ograniczeń związanych z życiem wśród osób słyszących. Kiedy głucha osoba działa wśród słyszących, doświadcza zniechęcenia, poddaje się, tłumi emocje, odczuwa stres, obciążenie, przymus, opuszczenie, zdziwienie itd. Dlatego wyjście poza ten wszechogarniający klimat emocjonalny zawsze zasługuje na dokładny opis. Sukcesem jest nie tylko działanie, robienie tego, co się kocha, ale także przełamanie barier w kontakcie ze słyszącymi, zaistnienie w świecie słyszących jako partner, a nie osoba potrzebująca pomocy. Żeby tego dokonać, trzeba znaleźć własny, głuchy sposób działania. Dobrym tego przykładem jest fragment wywiadu z Radką Novákovą, redaktorką czeskiej telewizji:

Byłam pierwszą Głuchą, która zaczęła pracę bez niczyjej pomocy. Sama musiałam dojść do wszystkiego. to znaczy sama musiałam przygotować wiadomości w tekście, jak i w migowym.

Po 3 latach pracy miałam dosyć monotonii pracy wśród słyszących.

Też chciałam koordynować zespół Głuchych.

Porozmawiałam z innymi Głuchymi o zmianach w pracy z TV. Chciałam być szefem zespołu głuchych, nadzorować ich pracę, wybierać nowych ludzi na stanowiska. Słyszący tak robią więc dlaczego mam tego nie robić? Też chciałam koordynować zespół Głuchych.

W tej sprawie poszłam z tłumaczem do szefa TV i złożyłam swoją propozycję, na co on przystał na wszystkie warunki. Byłam szczęśliwa, bo dzięki temu Głusi mieli pracę. Jestem szefową, a zespół składa się z 5 osób ${ }^{11}$.

W przywołanym fragmencie opisu działania pojawia się kilka elementów, które są charakterystyczne dla wypowiedzi osób głuchych: po pierwsze - podkreślenie włożonego wysiłku i samodzielności w dochodzeniu do pozycji, którą się zajmuje; po drugie - zwrócenie uwagi na dyskomfort pracy w środowisku osób słyszących; po trzecie - użycie porównania i żądanie, żeby osoba głucha miała to samo, co osoba słysząca; po czwarte - kolektywne podejmowanie decyzji, zasięganie opinii, omawianie sprawy z innymi głuchymi; po piąte - konfrontacja ze słyszącym. Żeby

11 Wywiad z Radką Novakową, min. 2:28 i dalej, http://www.gluchapolkapotrafi.pl/ wywiady. 
zmierzyć się ze słyszącym szefem, trzeba być odpowiednio przygotowanym. Oznacza to także zadbanie o obecność zaufanego tłumacza języka migowego. Dlaczego? Osoba tłumacza nie tylko gwarantuje sprawną komunikację. Tłumacz jest świadkiem spotkania, jest kimś, kto może potwierdzić „moją”, „głuchą” wersję wydarzeń. Tłumacz to sposób na to, żeby zapobiec możliwym manipulacjom ze strony osoby słyszącej. Bo przecież w sytuacjach normalnych, zwykłych, codziennych tłumacz nie jest potrzebny. Ze słyszącymi można się porozumieć na piśmie. Ale w sytuacjach ważnych i wyjątkowych warto skorzystać z usług tłumacza. Ostatnim, szóstym elementem charakterystycznym, który wystąpił w przytoczonej opowieści, jest wskazanie na emocje. Radość pojawiła się nie tylko dlatego, że zostały zaspokojone osobiste ambicje. Zadowolenie dotyczy w dużej mierze tego, że samotność w świecie słyszących została przełamana.

\section{Tekst migowy}

We vlogu zatytułowanym „Skąd wiem, że Głucha Polka potrafi?”, opublikowanym 12 listopada 2014 roku, Iwona Krawczuk opowiada własną historię:

Chcę Wam dzisiaj opowiedzieć krótką historię dotyczącą mojego życia i tego, jak dzięki swojej pracowitości i zaangażowaniu spełniać swoje marzenia i dążyć do osiągnięcia swoich celów. Byłam w ósmej klasie szkoły podstawowej. Przed zakończeniem ostatniego roku podstawówki wysłano nas do psychologa szkolnego, żeby wydał opinię na temat tego, w jakim typie szkoły powinniśmy kontynuować naukę. Spotkałam się z panią psycholog. Najpierw dostałam testy psychologiczne do zrobienia (niektóre były trudne, inne łatwe), a później rozmawiałyśmy osobiście. Po zebraniu wszystkich testów i przeanalizowaniu moich odpowiedzi pani psycholog stwierdziła, że najlepszym zawodem dla mnie byłoby... krawiectwo. Padłam z wrażenia! Byłam w szoku! Ja mam być krawcową? To niemożliwe! Pani psycholog stwierdziła: „No tak”. Zaskoczona nie zgodziłam się z nią i spytałam, dlaczego tak uważa. Pani psycholog odpowiedziała mi bardzo wymijająco. W końcu spytałam ją: „Czy to dlatego, że jestem Głucha?” Stwierdziła, że nie mam szans rozwijać się zawodowo, a liceum będzie dla mnie za trudne. Twierdziła, że sobie nie poradzę. Powiedziałam jej, że absolutnie się z tym nie zgadzam i że pójdę do liceum ogólnokształcącego - tak jak zawsze chciałam. A w tym czasie nie miałam nawet pojęcia, czy istnieje LO dla niesłyszących. Nigdy nie zapomnę tego, co mi powiedziała pani psycholog. Uważała, że Głusi mają mniejsze szanse na rozwój zawodowy. Jakby Głusi mieli mniejsze możliwości. Ja jednak powiedziałam, że nie zgadzam się z jej opinią. I co? Poszłam do liceum dla słyszących, w którym byłam jedyną Głuchą. Udało się! Na dodatek chciałam jeszcze skończyć studia. Udało się! Później przeprowadziłam się do Warszawy, gdzie chciałam pracować jako sekretarka... i to też się udało! A przecież jestem Głuchą Polką... Udało mi się to wszystko dzięki mozolnej pracy i wierze w siebie.

Iwona odpowiada na pytanie postawione w tytule swojego nagrania, przywołując historię z własnego życia. W tym przypadku dyskurs dotyczący możliwości 
głuchych przejawia się $\mathrm{w}$ akcie niezgody na przypisywanie cielesności osoby głuchej jakichkolwiek ograniczeń. Ważniejsze od możliwości czy niemożliwości odbierania konkretnych wrażeń zmysłowych okazały się marzenia, wola i chęci. Można by powiedzieć, że to właściwie zwykły tekst motywacyjny. Ale tak się tylko wydaje, gdy spoglądamy na tłumaczenie w języku polskim. Przyjrzyjmy się teraz treści vloga w alternatywnej formie zapisu. Poniżej transkrypcja tekstu migowego z wykorzystaniem glosowania.

WITAM WY. CHCĘ OPOWIADAĆ WY KRÓTKO HISTORIA MOJE ŻYCIE JAK DZIĘKI STARAĆ SIĘ PRACOWAĆ MARZENIE WYKONAĆ UDAĆ SIĘ DAWNO DAWNO BYĆ ÓSMA KLASA TO ZNACZY SZKOŁA PODSTAWOWA ZARAZ PODSTAWOWA KONIEC PRZED MOJA KLASA W TYM JA GRUPA-ruch PSYCHOLOG

PO CO (pytanie - mimika) ON-wsk OPINIA O WARTOŚĆ PRZYSZŁOŚĆ SZKOŁA PÓJŚĆ JA dwie osoby stają naprzeciwko siebie - klasyfikator PSYCHOLOG dwie osoby stają naprzeciwko siebie - klasyfikator DAĆ - kier TEST PSYCHOLOG PYTAĆ BYŁO TRUDNO mimika INNY ŁATWO POTEM ROZMOWA PSYCHOLOG dwie osoby stają naprzeciwko siebie - klasyfikator WSZYSTKO JUŻ ZEBRAĆ WYNIK BADANIE POWIEDZIEĆ kier CO BYŁO MÓJ NAJLEPIEJ ZAWÓD PRZYSZŁOŚĆ CO pytanie - mimika KRAWIEC SZCZĘKA OPAŚĆ mimika JA SZOK JA pyt-mimika KRAWIEC JA pyt-mimika NIEMOŻLIWE [ręce rozłożone, zmiana ról] JA mimika SZOK. JA zaprzeczenie głowa mimika NIE ZGADZAĆ OSOBA - wsk TWOJA OPINIA NIE ZGADZAĆ JA mimika PYTAĆ-kier TY-wsk DLACZEGO UWAGA gest pytanie mimika PSYCHOLOG ODPOWIADAĆ-kier MANIPULACJA JA PODOBNY PRZYMUS TY POWÓD JA GŁUCHY pytanie - mimika JA-wskazanie na ciało O TO CHODZI pytanie mimika ON-wsk POWIEDZIEĆ - kier JEŻELI JA PÓJŚĆ LO UPAŚĆ-NA-PLECY mimika, ruch JA mimika-neg PORADZIĆ TRUDNY JA mimika-neg NIE ZGODZIĆ SIĘ JA ZGODZIĆ SIĘ LO PÓJŚĆ ZGODZIĆ SIĘ mimika ALE OKRES -wsk PODSTAWOWA OKRES TU-wsk NIE WIEDZIEĆ JEST SZKOŁA GŁUCHY LO NIE WIEDZIEĆ mimika DLACZEGO PÓJŚĆ-kier LO

JA W-OGÓLE mimika-neg ZAPOMNIEĆ TA-wsk PSYCHOLOG POWIEDZIEĆ-DO MNIE-kier gest ALE UWAGA GŁUCHY PODOBNY MIEĆ-kier MAŁY - klas MAŁO OKAZJA ROZWÓJ ZAWÓD gest

gest PODOBNY GŁUCHY ODSTAWIĆ-NA-BOK - klas gest

ALE JA POWIEDZIEĆ -kier mimika NIE ZGODZIĆ SIĘ CO ROBIĆ mimika-pytanie PÓJŚĆ-kier LO W-TYM SŁYSZĄCY OSOBA-JEDNA-klas GŁUCHY OSOBA-JEDNA-klas W-TYM CO mimika-pytanie UDAĆ SIĘ POTEM SKOŃCZYĆ SIĘ STUDIA UDAĆ SIĘ PRZENIEŚĆ SIĘ - ruch WARSZAWA GDZIE mimika-pyt PRACA MARZYĆ JA TERAZ BIURO MARZENIE WYKONAĆ UDAĆ SIĘ ALE JA BYĆ GŁUCHA POLKA CIAŁO-MOJE - wsk mimika PRAWDA WSZYSTKO DZIĘKI PRACA mimika ruch ZAKASAĆ RĘKAWY PRACOWAĆ mimika WIARA SIEBIE

Transkrypcja przybliża w pewnym stopniu obrazy, jakie otrzymuje odbiorca tekstu migowego. Dzięki temu uwidocznione zostały fragmenty pozaleksykalne, jednak niosące wyraźne znaczenie, związane z mimiką, gestami i ruchem. Są to gramatyczne i pozagramatyczne elementy tekstu, które widzi jego głuchy 
odbiorca posługujący się językiem migowym. Jakie treści niosą te właśnie elementy? Zacznijmy od ruchu. Ruch ma wiele funkcji. W przypadku czasowników kierunkowych, jak np. POWIEDZIEĆ, wykonywany ruch „od nadawcy” lub „do nadawcy" wskazuje na to, kto do kogo mówi. Innymi słowy, w tekście migowym w odniesieniu do pewnej grupy czynności widoczny jest - poprzez zaznaczenie w przestrzeni migania - określony rodzaj współpracy między dwiema lub więcej osobami, np. w znaku POWIEDZIEĆ widać, kto do kogo mówi, w znaku DAWAĆ widać, kto komu i co daje, w znaku POMAGAĆ widać, kto komu pomaga. Ruch służy również określaniu sposobu oraz intensywności wykonywanej czynność za pomocą ruchu Iwona pokazała, jak ciężko musiała pracować, żeby osiągnąć sukces. W transkrypcji uwidocznione zostało także użycie konstrukcji klasyfikatorowych ${ }^{12}$ i elementów pantomimicznych, które także stanowią jednostkę składniową ('́widziński, Rutkowski 2014: 153). Oznacza to, że osoba migająca może włączyć w tekst migowy fragmenty naśladujące kształt, ruch czy wygląd danego elementu rzeczywistości w celu uzyskania odpowiedniej intensywności opisu.

W przedstawionej transkrypcji tekstu migowego uwidocznione zostały także elementy mimiczne, które mogą posiadać rozmaite znaczenia. Najczęściej poprzez ludzką twarz wyraża się i odczytuje różnego rodzaju emocje. Jakie znaczenie dla praktyk epistemicznych ma fakt włączenia mimiki do repertuaru narzędzi gramatycznych, za pomocą których konstruuje się określone wypowiedzi w języku migowym? Z reguły głuche dzieci, które posługują się językiem migowym od urodzenia, $\mathrm{w}$ wieku siedmiu lat $\mathrm{w}$ pełni opanowują elementy mimiczne pełniące funkcje gramatyczne (Eliot, Jacobs 2013). Dla odbiorców języka migowego mimika świadczy o biegłości językowej, a co za tym idzie - o bogactwie doświadczeń jako osoby głuchej. To właśnie natywni głusi użytkownicy języka migowego najswobodniej i najpełniej wykorzystują gramatyczne funkcje mimiki, którą można traktować jako świadectwo ich pokoleniowego trwania w doświadczeniu głuchoty.

\section{Hasła}

Jak przystało na blog motywacyjny, także i tutaj obowiązuje zasada, wedle której każdy jest kowalem własnego losu. Jak miga Iwona Krawczuk w podsumowaniu serii swoich wywiadów, to nie głuchota jest przyczyną niepowodzeń osób

12 „W lingwistyce migowej termin „klasyfikator” odnosi się do znaku o funkcji anaforycznej, uwzględnionego pod względem jakiejś cechy ze swoim antecedensem. Cecha ta wskazuje zazwyczaj na kształt i rozmiar obiektu, ale w niektórych wypadkach także na inne właściwości, np. żywotność (...). Klasyfikatory mogą pełnić funkcję anaforyczną w stosunku do dowolnego obiektu, czyli m.in. osób, zwierząt, przedmiotów (...). Klasyfikatory przedmiotowe nawiązują swym kształtem do kształtu obiektu (a zatem wyprostowana dłoń może odnosić się do przedmiotu płaskiego) lub do sposobu operowania danym przedmiotem przez człowieka (np. sposobu trzymania w wypadku narzędzi). Dostępność i potencjał zdaniotwórczy klasyfikatorów powoduje, że wiele zdań migowych pozbawionych jest zleksykalizowanych znaków czasownikowych. Jeśli bowiem gramatyka migowa dopuszcza przesunięcie klasyfikatora jako komunikat dotyczący przemieszczania się obiektu, redundantne staje się użycie czasownika (np. JEŚĆ lub JECHAĆ)" (Rutkowski, Łozińska 2011: 214). 
niesłyszących, ale ich brak wiary we własne siły. Zgodnie z tym przekazem należy odważyć się i nie ukrywać tego, że jest się głuchym. Podążanie za marzeniami, pasja, dyscyplina i wytrwałość - oto czynniki sukcesu. Na blogu pojawia się też charakterystyczna gra znaczeń zachęcająca do sprzeciwu wobec sytuacji, w których to inni ludzie decydują o losie osób głuchych: „Jesteś Głuchy?”, więc „Nie słuchaj". Wywiady obfitują w hasła skierowane do osób głuchych: "głuchota nie jest ważna", "głuchota może być atutem", "głusi mogą mieć wpływ na słyszących". Wezwaniem generalnym jest: weź przykład ze mnie - jestem głuchy/głucha i mogę.

Dlaczego w zestawie praktyk epistemicznych osób głuchych znalazło się także formułowanie haseł, których funkcją jest przełamywanie dyskursu niemocy? Kate Zamana, słabosłysząca uczestniczka wypraw polarnych z psimi zaprzęgami, odkryła mechanizm, którego przełamaniu służą hasła:

- Co jest Twoim największym sukcesem życiowym?

- Niezależność i wolność. Ja to w sobie sama wyrobiłam. Nie chodzi mi tylko o zewnętrzną niezależność i wolność. Ja mam swoje miejsce na ziemi. Mieszkam sama, sama o sobie decyduję. Najważniejsza jest niezależność wewnętrzna. Ja nadal nad tym pracuję. Dzięki temu kontroluję swoje bariery, słabości, negatywne informacje ze swojej podświadomości, które zostały zakodowane w przeszłości. Podam taki przykład - jak ktoś mi mówi, ty nie będziesz aktorką, bo masz wadę słuchu, mówisz z błędami, to powoduje bariery, buduje fałszywe moje ja. Najważniejsze, że jestem tego świadoma, czego chcę, a co jest fałszywymi informacjami. Bariery, niewłaściwe kody chcę zmienić ${ }^{13}$.

Pod pozorami wypowiedzi dotyczącej mechanizmów psychologicznych ukryta została tutaj opowieść o dostępie do wiedzy i informacji. „Fałszywe informacje” zalewają podświadomość i przyczyniają się do powstawania barier. Istnienie takich informacji implikuje istnienie innych - tych prawdziwych, tych właściwych. Używanie haseł, porad, sformułowań dotyczących potęgi głuchoty ma za zadanie przypominać o tym rozdwojeniu. Informacjom fałszywym trzeba przeciwstawiać informacje właściwe. Zadaniem haseł jest wzywanie do właściwych praktyk epistemicznych, do produkowania informacji, które nie będą „fałszywe”, do tworzenia „właściwych kodów”.

\section{Zakończenie: Praktyki epistemiczne - praktyki somatosensoryczne}

Jak zauważa Donna Jo Napoli, medium języka migowego ma charakter somatosensoryczny, czyli odnoszący się do wrażeń płynących z tych części ciała, które nie są bezpośrednio związane z organami zmysłów:

Wprawdzie mowa jest artykułowana z wykorzystaniem traktu głosowego i w ten sposób fizycznie angażuje części ciała osoby mówiącej, to jednak znaczenie wypowiedzi jest w znacznym stopniu arbitralnie powiązane z tym zaangażowaniem.

13 Wywiad z Kate Zamana, min. 19:09 i dalej, http:// www.gluchapolkapotrafi.pl/wywiady. 
Język migowy jest wyrażany przez znacznie więcej części ciała - ręce i twarz ruchy, kształty i pozycje ciała osób migających są w znacznie większym stopniu powiązane ze znaczeniem, przez co migający doświadcza innego języka na poziomie poznawczym; system somatosensoryczny i mechanizm językowy w mózgu zasilają się synergicznie. Język staje się znakiem; osoba migająca staje się językiem (Napoli 2014: 224-225).

Trop somatosensoryczny przybliża nas do istoty zmysłowego doświadczenia osób głuchych. Pojęciowe uwikłanie w sensoryczną opozycję między wzrokiem a słuchem zawsze utrudniało zrozumienie tego, że głuchota nie oznacza po prostu braku jednego ze zmysłów (Rée 1999: 323). Nie jest ona także równoznaczna z kompensacją słuchu przez inne zmysły, np. wzrok czy dotyk. Idea somatosensoryczności każde myśleć o głuchocie jako pewnej specyficznej kondycji cielesnej. Kondycję tą należy rozumieć przede wszystkim jako pełnię. Praktyki epistemiczne głuchych są związane z pozyskiwaniem i przekazywaniem wiedzy dotyczącej tego, w jaki sposób można w praktyce zrealizować tą pełnię. Dyskurs dotyczący „możliwości Głuchych" przeciwstawia się narracji o głuchocie będącej synonimem braku. Praktyki epistemiczne głuchych związane są z bezpośrednim wskazywaniem na głuchotę jako kondycję cielesną oraz przywoływaniem rozmaitych jej kontekstów. Konieczny jest też opis sposobu działania, właściwego wskazanej kondycji cielesnej - opis tym bardziej szczegółowy, że dokonany $\mathrm{w}$ języku migowym z wykorzystaniem ruchu i mimiki. Praktyki epistemiczne głuchych opierają się na założeniu cielesnej pełni zanurzonej w świecie fałszywych informacji, które przyczyniają się do powstawania barier. Te ostatnie mają jednak charakter wyłącznie mentalny. Wystarczy bowiem znać odpowiedni sposób działania, żeby cielesna pełnia mogła się zrealizować.

\section{Literatura}

Bahan, B. (2014). Senses and Culture: Exploring Sensory Orientation (s. 233-254). W: H-D. L. Bauman, J.J. Murray (eds.), Deaf Gain. Raising the stakes for human diversity. Minneapolis, London: University of Minnesota Press.

Blankenmeyer Burke, T. (2014). Armchairs and stares. On the privation of deafness (s. 3-22). W: H-D. L. Bauman, J.J. Murray (eds.), Deaf Gain. Raising the stakes for human diversity. Minneapolis, London: University of Minnesota Press.

Byrd, T., Consoli, J.T. (2007). Deaf Space. Gallaudet Today: the Magazine, Spring.

Czajkowska-Kisil, M. (2014). Opis gramatyczny polskiego jezyka migowego, niepublikowana rozprawa doktorska. Warszawa: Uniwersytet Warszawski, Wydział Polonistyki.

De Clerck, G.A.M. (2012). Contributing to an era of epistemological equity: a critique and an alternative to the practice of science (s. 19-44). W: P.V. Paul, D.F. Moores (eds.), Deaf Epistemologies. Multiple perspectives on the acquisition of knowledge, Washington: Gallaudet University Press.

Elliott, E.A., Jacobs, A.M. (2013). Facial Expressions, Emotions, and Sign Languages. Frontiers in Psychology, 4(115), 1-4.

Friedner, M., Helmreich S. (2012). Sound Studies Meets Deaf Studies. Senses E Society, 7(1), 72-86. 
Howes, D. (2003). Sensual Relations: Engaging the Senses in Culture and Social Theory. Ann Arbor, Mi: University of Michigan Press.

Jankowski, K.A. (1997). Deaf Empowerment: Emergence, Struggle and Rhetoric. Washington: Gallaudet University Press.

Jonathan, R. (2000). I see a voice. A philosophical history of language, deafness and the senses. London: Flamingo.

Levänen, S., Hamdorf D. (2001). Feeling vibrations: enhanced tactile sensitivity in congenitally deaf humans. Neuroscience Letters, 301, 75-77.

Łozińska, S. (2012). Gramatyczne funkcje ruchu w polskim języku migowym (PJM) (s. 89-97). W: K. Lisczyk-Kubina, M. Maciołka (red.), Ruch w jezyku - jezyk w ruchu. Katowice: Wydawnictwo Gnome.

Napoli, D.J. (2014). A magic touch. Deaf Gain and the benefits of tactile sensation (s. 211232). W: H-D.L. Bauman, J.J. Murray (eds.), Deaf Gain. Raising the stakes for human diversity. Minneapolis, London: University of Minnesota Press.

Padden, C., Humphries, T. (2005). Inside Deaf culture. Cambridge, MA: Harvard University Press. Podgórska-Jachnik, D. (2013). Głusi. Emancypacje. Łódź: Wydawnictwo Naukowe Wyższej Szkoły Pedagogicznej.

Rée J. (1999). I see a voice. A philosophical history. London: HarperCollins Publishers.

Rutkowski, P., Łozińska S. (2011). O niedookreśloności semantycznej migowych predykatów klasyfikatorowych. W: M. Bańko, D. Kopcińska (red.), Różne formy, różne treści (s. 211-224). Warszawa: Wydział Polonistyki Uniwersytetu Warszawskiego.

Świdziński M., Rutkowski P. (2014). Ikoniczność nieleksykalna: reprezentacja referencjalna jako składnik tekstu w językach wizualno-przestrzennych. W: P. Rutkowski, S. Łozińska (red.), Lingwistyka przestrzeni i ruchu. Komunikacja migowa a metody korpusowe. Warszawa: Wydział Polonistyki Uniwersytetu Warszawskiego.

Źródła internetowe:

http://www.gluchapolkapotrafi.pl/wywiady [dostęp: 10.10.2017].

https://www.facebook.com/G\%C5\%82ucha-Polka-Potrafi-1492402737666868/ [dostęp: 10.10.2017].

https://www.youtube.com/watch?v=BfilMGDkzHg [dostęp: 10.10.2017].

http://techtv.mit.edu/videos/3435-speakers-and-signers-ben-bahan-deaf-ways-extending-sensory-reach [dostęp: 10.10.2017].

\section{SUMMARY}

Epistemic practices of the deaf

The article presents an analysis of interviews with and for deaf people posted on the website of the project "Deaf Poland Can". The topic of the analysis are epistemic practices of deaf people, i.e. both the content of deaf people's knowledge and the ways of gaining this knowledge. Epistemic practices of deaf people have a twofold reference to sensuality. On the one hand, it is noticeable at the level of discourse, which shows the possibilities of a deaf person and his/her specific bodily experience. On the other hand, it is visible at the sign-language level, where elements such as motion and visuality give the descriptions a particular kind of precision.

Keywords: Deaf, deafness, embodiment, epistemology, discourse, practice 